\title{
Soror nostra es: Jesuits, Protestants, and Political Elites in Southern Africa among the Shona and the Ndebele, $1889-1900$
}

\author{
Aquinata Agonga
}

Historical archives overflow with nineteenth-century accounts of the heroic incursions of missionaries into the African hinterlands, equipped with minimal resources and even less knowledge about their destinations. Tales of young missionaries newly arrived in southern Africa, braving rain, rivers, treacherous paths, diseases, and unknown terrain along the Zambezi to lands lying in the deepest interior of the African continent can be found on shelves in libraries around the world. Along their paths, the missionaries built prayer hamlets that would constitute the foundations of one of the most enduring legacies of this missionary age.

Unfortunately for Africa, its missionary fate was largely instigated by Western colonialism and its aftermath, born of a series of events that marked the second half of the nineteenth century. ${ }^{1}$ Europe, experiencing the climax of industrialization, stood in dire need of markets for products and raw materials for production. The reports and narratives of Europeans returning home from short stints as explorers, hunters, traders, and missionaries in Africa about a continent as vast in mass as it was rich in resources fell on eager ears. ${ }^{2}$ Soon, European powers were stumbling over each other in their scramble for the continent. As political leaders sliced up the continent, European Christian authorities busied themselves with drawing parallel fault-lines along which they would plant the seeds of the Gospel.

The battle for a share of the continent and its resources was just as spiritual as it was political. The dramatic arrival of the missionaries in Matabeleland started as early as $1859 .^{3}$ Through Robert Moffat (1795-1883), the London Missionary Society (LMS) had sought to establish a mission station

1 Donald Denoon and Balam Nyeko, Southern Africa since 1800 (London: Longman Group, 1984), 117 .

2 Lewis H. Gann, A History of Southern Rhodesia: Early Days to 1934 (London: Chatto \& Windus, 1965), 18.

3 Ibid.

(C) AQUINATA AGONGA, 2018 | DOI 10.1163/9789004347151_008

This is an open access chapter distributed under the terms of the prevailing CC-BY-NC-NDLicense. 
in Matabeleland, then under Chief Mzilikazi (c.1790-1868), ${ }^{4}$ who, unlike Chief Khama III (c.1837-1923) of the Bamangwato, and for reasons other than genuine interest in the spiritual message his strange guests claimed to bear, allowed the missionaries to settle in the territory and train his people. ${ }^{5}$ The chief pledged to give them any help they needed as they went about their duties. He encouraged his subjects to listen to the strangers and often availed himself during the services held on Sundays. ${ }^{6}$

Although the chief participated in some of the activities of the early missionaries, he had his own reasons for welcoming them among his people, ${ }^{7}$ as he hoped to use the missionaries as trading agents with white South Africa and as a channel for the acquisition of more firearms. Once the missionaries had settled, he thought that they would then link him with white South Africa. ${ }^{8}$ In general, African chiefs had acquired firearms that needed maintenance and, as such, they saw an opportunity in the missionaries who would be able to carry out the needed repairs. ${ }^{9}$ For their part, the missionaries saw an opening and a chance to evangelize and convert the Africans. ${ }^{10}$

It was thus clear from the outset that both parties started on a wrong footing, as the missionaries had been granted leave to enter these territories for reasons other than those for which they had originally sought entry. Most chiefs were more interested in the gifts the missionaries brought along, as well as the services the missionaries were prepared to offer. The chiefs also opened up their territories on the misconceived idea that these strangers would give them protection in times of war.

The missionaries, like their colonial counterparts, possessed firearms that the chiefs required for wars. It is reported, for instance, that when Mzilikazi realized the threat posed to his chiefdom by the belligerent Zulu, or the powerful Boer armies, he dispatched his messenger, Mncumbata Khumalo

Mzilikazi (meaning the Great Road), was a south African king who founded the Matabele kingdom (Mthwakazi), Matabeleland, in what became Rhodesia and is now Zimbabwe. He was born near Mkuze, Zululand (now part of South Africa). He was the son of Matshobana, whom many had considered to be the greatest southern African military leader since the Zulu king Shaka (1787-1828, r.1816-28).

5 Sabelo J. Ndlovu-Gatsheni, "Who Ruled by the Spear? Rethinking the Form of Governance in the Ndebele State," African Studies Quarterly 10, nos. 2-3 (2008): 71-94, here 75.

6 Benedict V. Mtshali, Rhodesia: Background to Conflict (London: Leslie Frewin, 1968), 30.

$7 \quad$ Ndlovu-Gatsheni, "Who Ruled by the Spear?," 75.

8 Ibid.

9 Mtshali, Rhodesia, 3 .

10 Ngwabi Bhebe, Christianity and Traditional Religion in Western Zimbabwe, 1859-1923 (London: Longman, 1979), 27. 
(c.1780s-c.1872/73), to Kuruman with an invitation for Moffat. ${ }^{11}$ He viewed the missionaries as potential allies against his enemies, and he also sought to employ their services to improve trade relations with the outside world and to acquire superior arms. ${ }^{12}$ The chief and Moffat established an enduring friendship. Hugh Marshall reports that, on one occasion, the chief, while listening to Moffat's preaching, exclaimed, "I like you, I like you and you will be my father and I will call you by the name of my father Matshobane."13

The missionaries seem to have never suspected anything from the chiefs and their subjects other than pure interest in their message, simply assuming that the chiefs understood their mission and had a genuine desire for conversion. ${ }^{14}$ This failure to understand the motives behind the chiefs' invitations saw the missionaries toil for over twenty years without converting a single person..$^{15}$

The missionaries' encounter with Africa in the period after the Berlin Conference (1884-85) needs to be evaluated within its proper context. Missionaries affiliated to the two faith orientations arrived in Africa at the onset of what would become one of the most important events in the history of the continent, namely European colonialism. From the start, the encounter between Africa and colonialism was marked by suspicion, mistruths, hostility, and violence. ${ }^{16}$ The missionaries arrived at a time when revulsion for and suspicion of the white man were already hardening within Africa's collective consciousness. ${ }^{17}$ It did not help that the missionaries made little effort to dissociate themselves from the colonial authorities and in some cases ${ }^{18}$ actually rallied with the colonial forces in the many battles that Africa waged against the initial stages of colonialism. ${ }^{19}$

The remaining part of this chapter seeks to establish the relationship between the missionaries and the political administration among the Ndebele and the Shona in the period between 1880 and 1900 . The failure to convert even a handful of people in a decade pushed the missionaries into cooperating with the colonial administration in the fight against the Africans and their governments. The missionaries, perhaps out of frustration at the reluctance

\footnotetext{
11 Ndlovu-Gatsheni, "Who Ruled by the Spear?," 74.

12 Ibid.

13 Hugh Marshall Hole, Lobengula (London: Philip Allan \& Co., 1929), 12.

14 Robert Blake, A History of Rhodesia (London: Eyre Methuen, 1977), 27.

15 Julian Mockford, Seretse Khama and the Bamangwato (London: Staples Press, 1950), 44.

16 Ndlovu-Gatsheni, "Who Ruled by the Spear?," 80.

17 Mtshali, Rhodesia, 3 .

18 Ndlovu-Gatsheni, "Who Ruled by the Spear?," 81.

19 Jackson Mutero Chirenje, Chief Kgama and His Times, c.1835-1923: The Story of a Southern African Ruler (London: Rex Collings, 1978), 24.
} 
of Africans to convert or their own failure to understand the real motives behind the chiefs' eagerness to offer accommodation, ${ }^{20}$ gave their full support to the political elite under the British South Africa Company (BSAC) of Cecil Rhodes (1853-1902) as it sought to conquer and subdue the Ndebele. To the missionaries, both Catholic and Protestant, the chiefs had become obstacles to evangelization, and the colonial administration had become an ally in the process of eliminating those obstacles.

\section{Background}

The Catholic Church turned its attention to the Jesuits for the task of evangelizing the southern part of Africa. It chose to send its well-disciplined shock troop, as Jesuits were then perceived to be. ${ }^{21}$ The Jesuits themselves had a strong foundation in missionary work around the world, ${ }^{22}$ and, as Pope Pius VII (1742-1823, r.1800-23) would observe at the restoration of the Society in 1814, it would have been a disservice to the world if the church failed to employ the skilled rowers for the storm-tossed bark of Peter, whom the Society could provide. ${ }^{23}$ To the Jesuits, he gave a word of exhortation, urging them to be true to St. Ignatius of Loyola $(c .1491-1556)$, their co-founder, and to his legacy. ${ }^{24}$ As such, the Jesuits arriving in Africa were more than prepared for missionary work. ${ }^{25}$ However, the Jesuits encountered the same challenges as other missionaries. Their penetration into the interior was viewed as a threat to the lands and peoples that were controlled by African chiefs and, indeed, to the chiefs' own sovereignty.

There were different groups of Europeans arriving among the Ndebele and the Shona through what was then known as Bechuanaland, which is today's Botswana. These groups, which were motivated by a variety of interests, sought favors from the chiefs in different areas. Some came bearing gifts such as guns, beads, and drinks, while others, like the missionaries, came offering various skills as incentives. There were also hunters, miners, teachers, and politicians among the missionaries. These initial activities saw the chiefs and their

\footnotetext{
$20 \quad$ Mtshali, Rhodesia, 30.

21 Gann, History, 18.

22 William V. Bangert, A History of the Society of Jesus (St. Louis: Institute of Jesuit Sources, 1972), 429 .

23 Ibid.

24 Ibid.

25 Gann, History, $5^{8}$.
} 
subjects face a number of challenges in their attempts to understand what the strangers really wanted.

The royal kraals through which the missionaries sought access to African chiefdoms were essentially Africa's bastions of power against European invasion and, in fact, constituted the very repository of the customs that were the fabric that held these societies in place. ${ }^{26}$ The reigning African chiefs in whose kraals the missionaries arrived with the message of the Gospel were faced with difficult decisions: ${ }^{27}$ How could they determine the distinction between the missionary and the colonizer? Worse still, how could they admit foreigners who brought along a belief system that would ultimately end in the extinction of African customs? The foreigners thus posed a significant threat to their sovereignty. As Robert Blake aptly observes, for the African chiefs, leadership had never required so much wisdom. ${ }^{28}$

\section{The Missionaries in the Field}

The missionaries arriving in Africa assumed that black people were without religion ${ }^{29}$ and in need of salvation. ${ }^{30}$ As such, once the missionaries settled among the communities, they set out to teach the Africans the true religion with the aim of converting them. The remote probability that Africans had their own religion did not hold substance at all, and, to the missionaries, any concept of African religion was rooted in witchcraft and had to be done away with. ${ }^{31}$

The African chiefs, for their part, opened up their homes to the strangers in accordance with the African tradition of hospitality. As mentioned earlier, the Ndebele chiefs saw the arrival of the Christian missionaries as offering a means to pursue their own commercial interests and, particularly, their desire to acquire guns that were needed to defend the Ndebele state from every form of aggression. They also wanted access to missionary medicine and other modern goods and ideas. ${ }^{32}$ Mzilikazi and his successor Chief Lobengula Khumalo

\footnotetext{
26 Ibid.

27 Ndlovu-Gatsheni, "Who Ruled by the Spear?," 86.

28 Blake, History of Rhodesia, 27.

29 Sabelo J. Ndlovu-Gatsheni, "Beyond the Equator There Are No Sins: Coloniality of Being and Violence in Africa," Journal of Developing Societies 28, no. 4 (2012): 419-40, here 425.

3o Ibid.

31 Ibid.

32 Sabelo J. Ndlovu-Gatsheni, "Rethinking Religious Encounters in Matabeleland Region of Zimbabwe, 1860-1893," African Journal of History and Culture 1, no. 2 (2009): 16-27, here 20.
} 
$\left(1845^{-94}\right)^{33}$ were always very friendly to the missionaries, allowing them to live among their people, the Ndebele, and even giving them audiences on occasion. ${ }^{34}$ It was against this backdrop of chiefly hospitality that the Catholic Church sent its team of missionaries. The church turned its attention to the ancient mission fields on the Zambezi where the Jesuits had long laid a foundation for evangelization in the Kingdom of Monomotapa from as early as $1560 .{ }^{35}$ Having worked in Mozambique and Angola for close to two centuries before their suppression in 1773, the Jesuits had acquired credentials for missionary work in southern Africa and, after their order had been restored in 1814, the pope did not hesitate to send them back to that same field. The Jesuits arrived in the territory sometime in 1879, a few months after they had left Grahamstown in today's South Africa.

Chief Khama, who came of age at a time when his country was witnessing a huge influx of white foreigners, did not allow the Jesuits to settle in his territory. His father Sekgoma I (d.1875), though skeptical of the spiritual value of the white man's religion, had some regard for the education the missionaries offered and had sent little Khama, together with his brother and a few other relatives, to be educated by the LMS. ${ }^{36}$ Therefore, unlike the other chiefs the missionaries encountered, Khama was well informed about the affairs of the world and was well acquainted with the politics of colonization and of Christian evangelization.

Under their superior, Fr. Henri Depelchin (1822-1900), the Jesuit missionaries were faced with challenges ranging from poor knowledge of the land to a people who were highly indifferent to their religion. After Grahamstown, their first stop was Bechuanaland, where they had come close to establishing themselves in the pre-suppression period before abandoning the venture at the time of the suppression. ${ }^{37}$ In the interim, Protestant missionaries, specifically from the LMs, had moved in to fill the void. ${ }^{38}$ The Jesuits discovered that not only was Khama educated in the ways of the white man but that

33 The second and last king of the northern Ndebele people. Both names, in the Ndebele language, mean "the men of the long shields," a reference to the Ndebele warriors' use of the Zulu shield and spear.

34 Ndlovu-Gatsheni, "Who Ruled by the Spear?," 18.

35 Gann, History, 18.

36 Chirenje, Khama and His Times, 17.

37 Sidwell Mhaladi Gabatshwane, Introduction to the Bechuanaland Protectorate History and Administration (Botswana: Kanye, 1957), 47.

38 Jackson Mutero Chirenje, A History of Northern Botswana 1850-1910 (Rutherford: Fairleigh Dickinson University Press, 1977), 104. 
he also professed the Christian faith, having been baptized by the Protestant missionaries.

Despite being denied settlement, the Jesuits were received rather warmly by Khama, and this may have persuaded them not to despair. They trudged on northward, stopping next in Matabeleland, under the reign of Lobengula, who, unlike Khama, quickly allowed them to settle in the territory and train his people, ${ }^{39}$ although initially he insisted that he did not want them to stay permanently. Ten years later, after realizing the value of the activities that were being carried out by the missionaries, Lobengula gave the Jesuits ample land and allowed them to stay permanently. ${ }^{40}$

In 1887 , the Jesuits opened their first permanent mission at Empandeni under Peter Prestage, S.J. (1842-1907). ${ }^{41}$ Like their fellow missionaries under the LMS, the Jesuits did not succeed in converting a single person until $1893 \cdot{ }^{42} \mathrm{All}$ the missionaries attributed this failure to the governing system of the Ndebele. They had envisioned the conversion of a people held in bondage for a long time and were therefore surprised at the reluctance of the Africans to convert. ${ }^{43}$ Their initial surprise gradually turned into disappointment, and, as was indicated earlier, they attributed their failure to the chief at the heart of a system that, according to them, was cloaked in superstition and witchcraft. ${ }^{44}$ Once they had identified the stumbling block to their mission, they sought ways to destroy it.

According to Ngwabi Bhebe, Prestage claimed that "until the Matabeles are put down by brute force [...] they will never improve." 45 The missionaries had come to the conclusion that the only way to evangelize the Africans, particularly the Ndebele, was by destroying their system of governance. ${ }^{46}$ They thus welcomed the advent of white rule as a solution, as it implied the destruction of Lobengula and the conversion of his people to Christianity. ${ }^{47}$ Entailed in this approach was also the need for the missionaries to collaborate with the colonial powers. ${ }^{48}$ The Jesuits, true to the spirit of their co-founder and to the

39 Ndlovu-Gatsheni, "Who Ruled by the Spear?," 17-20.

40 Chengetai J.M. Zvobgo, A History of Christian Missions in Zimbabwe (Gweru: Mambo Press, 1996), 1.

41 Bhebe, Christianity and Traditional Religion, 29.

42 Ibid.

43 Ndlovu-Gastheni, "Who Ruled by the Spear?," 19.

44 Ibid

45 Bhebe, Christianity and Traditional Religion, 82.

46 Ibid., 82-83.

47 Zvobgo, Christian Missions in Zimbabwe, 1.

48 Ibid. 
apostolic zeal that was at the foundation of their Society, selflessly dedicated themselves to the mission, with far-reaching consequences. ${ }^{49}$

\section{Cooperation with the Political Elite}

As the missionaries realized they were not making any headway in the evangelization of the Africans, they came to the conclusion that there were Africans who had converted but who were reluctant to profess their faith in public due to the fear of being accused of witchcraft. They decided that such silent converts would require the protection of another form of government, which could be provided by the colonial elite. ${ }^{50}$ Commenting on the situation, Prestage said: "It is perhaps well that the crisis should come soon; as every year delays by those of this nation, who but for living under the present barbarous rule and debarred by their fear from embracing Christianity would otherwise become Christians. ${ }^{51}$ He further explained his failure to convert Africans in the following words:

Our failure at Empandeni was not owing to the unwillingness of the natives to learn, and even become Christians, but it was due to the overwhelming terror, engaged by the system of government, which seizes every native in the country, when it is a case of casting off their pagan customs to adopt the new system. ${ }^{52}$

It was this kind of disillusionment, resulting from their failure to make converts, that eventually led the missionaries to collaborate with the colonial powers to remove the rulers they considered an obstacle to their mission. ${ }^{53}$ Whether it was the intractable Khama, who had resisted the true Christian faith, which was Catholic as far as the Jesuits were concerned, or the astute but cunning Lobengula, who plotted to exploit the missionaries in order to enhance his royal power, or even the scheming Chief Moemba of the Tonga,

49 Véronique Wakerley, trans., Journeys beyond Gubuluwayo to the Gaza, Tonga and Lozi: Letters of The Jesuits' Zambesi Mission, 1880-1883, ed. Ray S. Roberts (Harare: Weaver Press, 2009), 147 .

5o Ndlovu-Gatsheni, "Rethinking Religious Encounters," 23.

51 Zvobgo, Christian Missions in Zimbabwe, 2.

52 Ndlovu-Gatsheni, "Who Ruled by the Spear?," 21.

53 Mtshali, Rhodesia, 3. 
who planned the murder of missionaries in order to inherit their possessions, all had to go in order to pave the way for the Gospel in Africa. ${ }^{54}$

While working with the Africans, the missionaries had noticed how the chiefs were feared and revered by their subjects. As such, they reasoned that it was out of this fear that they could not openly come out to join the missionaries. ${ }^{55}$ The missionaries concluded that they had to have a new form of governance in order to save poor Africans from their wicked rulers. In the process, Christian missionaries, both Catholic and Protestant, defamed African forms of worship, viewing them as signs of barbarity, and denounced Ndebele resistance to Western values and ideas. Having stayed in southern Africa without much success in converting the Africans to Christianity, Moffat had arrived at the conclusion that the Ndebele were nothing but an "army of warmongers [...]; a nation of murderers whose hand is against every man." He went on to describe them as "people who worshipped the god of war, rapine, beef-eating, beer-drinking and wicked." ${ }^{\prime 6}$ This view was taken a notch higher by Reverend David Carnegie (1864-1910) of the LMS in a prayer of 1889. In it, he specifically called for the destruction of the Ndebele kingdom, saying: "Oh! For liberty and freedom and a power to break the cords of this savage monarch! This done, then our mission will begin. It will be so until a new government is formed and just laws administered to the people." 57

In their frequent correspondence with their colleagues, both the Jesuits and the Protestants described the Ndebele kingship as a fount of absolute dictatorship and despotic government. ${ }^{58}$ In practice, they openly advocated for the destruction of the Ndebele kingdom as the only way to open up this part of the land to Western ideas and values, including Christianity. ${ }^{59}$ In cases where African protagonists were featured in the evangelization process, they were often vilified and viewed as an impediment to the mission, against whom the missionaries heroically battled. ${ }^{60}$

\footnotetext{
54 Wakerley,Journeys beyond Gubuluwayo, 165.

55 Frederic Perry Noble, The Redemption of Africa: A Story of Civilization, 2 Vols. (New York: Young People's Missionary Movement), 1:390-91.

$5^{6}$ Blake, History of Rhodesia, 22.

57 Holmberg Anderson, African Tribes and European Agencies: Colonialism and Humanitarianism in British South East Africa, 1870-1895 (Stockholm: Scandinavian University Books, 1966), 20.

58 Ibid., 22.

59 Ibid.

6o Chirenje, History of Northern Botswana, 17.
} 


\section{Collaboration between the Missionaries and the Political Elite}

The missionaries had learned some of the local African languages and had even translated some parts of the Bible into these languages. ${ }^{61}$ At the appropriate time, this would present an opportunity for them to work with both the colonial political elite and the indigenous African people, as they were well equipped to act as interpreters between the chiefs on the one hand and the colonial elites on the other as the two parties negotiated for political concessions. ${ }^{62}$

Rhodes, who acted on behalf of the BSAC, was anxious to work with the missionaries in order to avoid criticism from humanitarian groups in Britain and South Africa. ${ }^{63}$ As far as he was concerned, the collaboration would help him push for the company's agenda among the Ndebele and the Shona and, at the same time, keep away imminent threats from the Germans and the Boers. ${ }^{64}$ With their patience worn thin from the fruitless labors in Matabeleland, the missionaries were ready and willing to support a political takeover by a colonial political class. ${ }^{65}$

The company used the missionaries to push for its agenda to have exclusive rights to explore minerals in Matabeleland. ${ }^{66}$ Rhodes readily agreed to work with the missionaries of all faiths, promising them land and security in exchange for their cooperation and involvement with the company plans. He invited them to accompany the pioneer column as chaplains and to act as interpreters with the chiefs for concessions. ${ }^{67}$ Company representatives came to Lobengula with Reverend Charles D. Helm (1844-1915) of Hope Fountain Mission, an LMS agent, and John Moffat (1835-1918), son of Robert Moffat, as interpreters. ${ }^{68}$ It was Helm who succeeded in convincing Lobengula that what the company proposed was for the good of the Ndebele people. He managed to get Lobengula to put his fingerprint on the dotted line of the paper for the company to acquire sweeping and exclusive mining rights in Matabeleland and Mashonaland. These Protestant missionaries were thus party to the controversial Rudd Concession of 1888. To the missionaries generally, this concession

\footnotetext{
$61 \quad$ Ibid.

62 Ndlovu-Gatsheni, "Who Ruled by the Spear?," 20.

63 Blake, History of Rhodesia, 74.

64 Mtshali, Rhodesia, 3 o.

65 Ndlovu-Gatsheni, "Who Ruled by the Spear?," 22.

66 Zvobgo, Christian Missions in Zimbabwe, 2.

67 W.D. [William Daniel] Gale, Heritage of Rhodes (London: Oxford University Press, 1950), 10.

68 Ndlovu-Gasteni, Rethinking Religious Encounter, 22.
} 
was seen as a major step in helping them evangelize among the natives. Once the BSAC had acquired the rights to move freely in Matabeleland, the missionaries saw their last chance to evangelize and hoped that they could help change the Africans. They aimed to acquire land to build schools, churches, and hospitals. The concession gave the company power to move freely in the whole of Matabeleland, which at the time included the land of the Shona that Lobengula claimed to have under his control. ${ }^{69}$

\section{Rising Tension}

Although Lobengula rejected the Rudd Concession, the agreement that supposedly created it was still enforced because of the support it received from the missionaries. Because of this support, humanitarian groups were duped into believing that all was well in southern Africa. For their part, Africans could no longer separate the role of the missionaries from that of the colonialists, and the relationship between the whites and the Africans became strained, eventually culminating in the First Ndebele War of $1893 .{ }^{70}$ Commenting on the intensifying tension, Prestage stated: "Sacrificing one's life for religion is one thing, and it is to be hoped that there would be no fear on that score; but to be assegaid merely for being a white man is quite another thing and no man in sound reason can wish for that."71 The missionaries left their stations and joined the armies to put down the rebellion while other Europeans sought their own safety as the company pushed its army to suppress the rising. They were not ready to let go of what they had acquired with the support of the missionaries. At the height of the war, some of the missionaries felt a sense of remorse. As Bishop George W.H. Knight-Bruce (1852-96) of the Anglican diocese of Bloemfontein observed: "These days we think a great deal about the king and his people. Often, I begged to see the Matabele power broken but now when it is come to pass I feel very sore at heart. And yet I believe it's all for the best." 72

Despite such sentiments, however, the missionaries continued to support Rhodes's BSAC. Prestage wrote to his superiors regarding Rhodes's efforts to gain a foothold north of the Limpopo:

\footnotetext{
69 Gale, Heritage of Rhodes, 11.

70 Ibid.

71 As quoted in Zvobgo, Christian Missions in Zimbabwe, 2 (italics added).

72 Zvogbo, Christian Missions in Zimbabwe, 7.
} 
Our hope is that this company will bring about the downfall of this Matabele tyranny and the entrenchment of a more righteous government $[. .$.$] . Now there is a fair prospect of a peaceful adjustment of dif-$ ferences, a gradual bringing of the land under kindlier influences, and a speedy cessation of this fiendish raiding. ${ }^{73}$

\section{Working Together}

After the Ndebele War, Matabeleland came under white occupation, which created an opening for the missionaries in Africa. ${ }^{74}$ Writing to Henry Schomberg Kerr, S.J. (1838-95), Prestage, who had witnessed the raid of the Ndebele and had special interest in the fall of their state, explained:

Our failure at Empandeni was not owing to the unwillingness of the natives to learn and even become Christians but was due to the overwhelming terror engendered by the pagan system of government [...]; any native relinquishing the ways of his forefathers is branded a traitor and is a marked man doomed to be knocked on the head as the cause of ill, should any misfortune attend his family or the town where he is residing. This is the barrier to missionary enterprise in Matabeleland. I foresaw it before I went to Empandeni but I always hoped that someone would have the grace to break it down. ${ }^{75}$

Prestage was fully behind the government and gave it his total support, acknowledging to the government representative, Dr. Leander S. Jameson (1853-1917), that "the church gave her blessing to the contemplated punishment of the pagan chiefs." To him, the "government's involvement and crushing of the Ndebele state was the only satisfactory solution." 76 The Ndebele system of government was a system of iniquity and deviltry, he remarked, and when asked if he would telegraph his views that the Ndebele government had to be overthrown to Rhodes, he readily agreed, stating that the destruction of the Ndebele system of government was the only way to ensure the security of life and property of whites and blacks in Mashonaland. In August 1891, he

$\begin{array}{ll}73 & \text { Ibid., 8. } \\ 74 & \text { Ibid., 6. } \\ 75 & \text { Ibid., 7. } \\ 76 & \text { Ibid. }\end{array}$


wrote that "we must put down the Matabeles and then go on with our work as if nothing had happened and the sooner this happened, the better."77

\section{Collaboration on the Battlefield}

At one point, the missionaries were called upon to work with the company troops on the battlefield against the Ndebele. Fr. Marcus Barthelemy (18571913), for example, accompanied the troops as the chaplain during the campaign. ${ }^{78}$ In April 1893, he was assigned to Captain George Brand's patrol to the Gwanda District and was with them when they ran the gauntlet through the rebel impis (Ndebele soldiers or regiment) on the Tuli Road. ${ }^{79}$ At TabaZiKa Mambo, he assisted in carrying the wounded into the camp and comforted the dying from the government side. He also served under Colonel Herbert Plumer's (1857-1932) column in the Matopos. ${ }^{80}$

The Anglican missionaries had the Reverend Douglas Pelly (1865-1943) minister to the troops during the same campaign, and he was later appointed Anglican chaplain to the troops that left Salisbury for Bulawayo. On April 19, 1896, Pelly and the troops reached Fort Charter, where they found nearly all the troops from Makoni's district waiting to join. ${ }^{81}$ Here, the Wesleyan Methodist missionaries under Isaac Shimmin (1860-1947) were supporters of the BSAC and in favor of the company taking over Lobengula's territory. ${ }^{82}$ They were in total agreement with Prestage, the Jesuit, on the need to fight and destroy the Ndebele. ${ }^{83}$

In a letter to Reverend Hartley Marshall (1868-1928) of the Wesleyan Methodist Missionary Society, Shimmin emphatically reasoned that to hesitate fighting the Ndebele would pose a grave danger to the lives of the whites in Mashonaland if the Ndebele themselves were to return and fight. ${ }^{84}$ According

$77 \quad$ As cited in ibid.

78 Francis Richartz, S.J., "Chishawasha Today," Zambesi Mission Record 1, no. 14 (1901): 471-75, here 474 .

79 Bhebe, Christianity and Traditional Religion, 87.

80 Ibid.

81 Zvogbo, Christian Missions in Zimbabwe, 28.

82 H.O. Briggs, "New Development in Mashonaland and Matabeleland and the African Response to Christianity 1897-1918," 67, available online http://journals.co.za/docserver/ fulltext/zambezia/1891-1945/1/303.pdf?expires=1492096428\&id=id\&accname=guest\&che cksum=136A38F8ECoA8822742E19E105996CD6 (accessed April 13, 2017).

83 Gann, History of Southern Rhodesia, 18.

84 As cited in Zvogbo, Christian Missions in Zimbabwe, 27-28. 
to Shimmin, most whites, including missionaries, supported the need to fight the Ndebele:

I have spoken with hundreds of men and have heard from everyone the same opinion expressed that the Matabele question must be settled once and by force. On this point, the clergyman and the farmer, the English and the colonial are at one and however much we dread the horrors of warfare, in a case of this sort, it is the better choice of two evils..$^{85}$

At this point, the missionaries from all sides of the faith worked together with the understanding that they had a common enemy in the African chiefs. They would say soror nostra es to each other as a way of encouraging themselves in the mission they had undertaken ${ }^{86}$ that is, to fight on the side of the political elite against the African chiefs. ${ }^{87}$ The LMS agent, William Elliot (1865-1944), saw the victory of the colonial forces over the Ndebele as God's punishment on them for their past atrocities upon other black people. ${ }^{88}$

The BSAC under Rhodes kept its promise to give assistance in the form of security, land, grants, and financial support to the various missionary groups ready to work in the land. ${ }^{89}$ Shimmin viewed this as an opportunity for change and a chance of a lifetime to set up a mission station in Matabeleland. ${ }^{90} \mathrm{He}$ asked Rhodes for favors even before they had succeeded in putting down the Shona War of 1896-97, requesting that the company grant him and his mission stands in the townships in Matabeleland for church purposes, farms for mission work, and an additional grant of a hundred pounds per year for five years. ${ }^{91}$ While writing home about his meeting with Rhodes, he claimed:

To this entire matter, he immediately agreed and promised to send me a formal letter $[\ldots]$. He went on to say that he made this promise willingly and with great pleasure as he regarded mission work as one of the best means for opening up and civilizing a country and that he had already

\footnotetext{
85 As quoted in ibid., 8.

86 Latin for "thou art our sister"; from Genesis 24:60 "They blessed Rebekah, and said unto her, Thou art our sister, be thou the mother of thousands of millions, and let thy seed possess the gate of those which hate them."

87 Richartz, "Chishawasha Today," 474.

88 Zvogbo, Christian Missions in Zimbabwe, 9.

89 A. [Anthony] J. Dachs and W.F. [William Francis] Rea, The Catholic Church and Zimbabwe 1879-1979 (Gwelo: Mambo Press, 1979), 52-54.

$90 \quad$ Zvogbo, Christian Missions in Zimbabwe, 11.

91 Ibid., 4.
} 
received convincing proofs of the good accomplished by the Wesleyan Church in Mashonaland. ${ }^{92}$

In March 1894, Rhodes instructed the BSAC administrator to inform Shimmin in writing that the company would grant the Wesleyans a subsidy of one hundred pounds annually for five years for their new mission in Matabeleland, as well as such land as might be required for mission work. ${ }^{93}$ It was not to the Wesleyans alone that such favors were advanced by the company. In the same year, Rhodes granted the missionaries of the Seventh-day Adventist Church a twelve thousand-acre farm at Solusi, and in 1895, the LMS were given twentyfour thousand acres of land at Dombodema. For his part, the Anglican bishop of Bloemfontein had been advocating for the establishment of a British protectorate over the Shona in order to protect them from what he understood to be inhuman cruelties meted on them by the Ndebele. When appointed to take charge of the new diocese, he went to Jameson, the administrator, to discuss the issue of land for Anglican missions. ${ }^{94}$ Rhodes honored his commitment and instructed the company to give the Anglicans six hundred British pounds for the expenses of Anglican missions in Mashonaland. ${ }^{95}$

The Jesuits were not forgotten in this colonial distribution of the spoils. Their first interest had been to acquire land and, toward this end, Rhodes ordered Archibald Colquhoun (1848-1914), the first administrator of the newly acquired territory, to give them every help. The administrator wrote: "Father Prestage tells me that Father Hartmann's knowledge regarding the ground suitable for a mission station is rather limited but no doubt, Mr. Heaney or one of the pioneers will give him help and advice in this matter as required."96 What Andrew Hartmann, S.J. (1851-1920) settled for was not good enough according to Prestage, for when he arrived after the second inspection, he found a better site beyond the boundaries they had been assigned. An exchange was arranged with the BSAC to take over the Chishawasha Valley. ${ }^{97}$ In recognition of their services, the company gave the Jesuits a farm consisting of twelve thousand acres of land. It was on this land that the Chishawasha Jesuit mission was founded. ${ }^{98}$

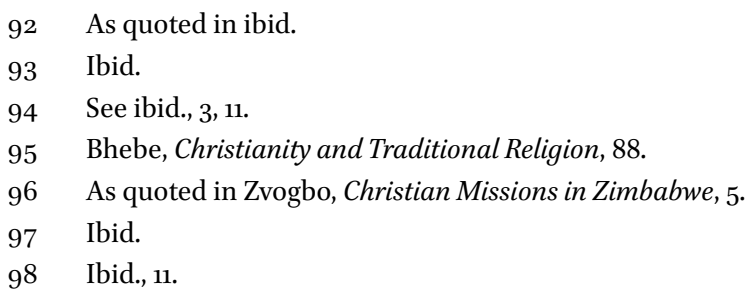




\section{The Missionary Settlement and Work on the Land}

The development of the Chishawasha mission was remarkable. The missionaries derived pleasure and gratification from their success at the farm, and it became an attraction that brought all the prominent people in Salisbury to visit. ${ }^{99}$ Commending the good work done by the Jesuits at Chishawasha, Colonel Frank W. Rhodes (1858-1902) had this to say: "The Jesuits have deserved well of Rhodesia and the Chartered Company. Take Chishawasha alone: what an advertisement Chishawasha has proved to the Chartered Company, the show place of Rhodesia." ${ }^{100}$ The farm provided the model beneficial Victorian expansion; this opened doors in the company that the Jesuits put to use whenever there was need to.

Once settled in their daily duties of social ministry and teaching, the Catholic missionaries also performed some tasks for the BSAC, which had become the official administrative authority among the Shona and the Ndebele. ${ }^{101}$ For example, the administration made an arrangement whereby the people would pay their taxes to the indunas (councilors or headmen) but collect the receipt from the missionaries.

\section{Conclusion}

Having come with a plan to preach and convert the Africans, the missionaries perceived the African way of life as heathen and treated everything African with contempt. They strove to convert the Ndebele in the usual way by preaching the Gospel to them. Yet despite the intensified missionary activities in the area, there were very few converts between 1870 and 1889 , and the missionaries came to the conclusion that their main obstacle was the governance system and that the system had to be replaced. They recognized that a different kind of governing system was required to win over the Africans, and so when the BSAC came calling and seeking their assistance, they were more than willing to offer help. Here we come across an interesting case of encounter between Jesuits and Protestants, which was brought about by their need to collaborate with the colonial elites in order to remove African indigenous leadership. Moreover, once they had identified the need they had for each other, the missionaries and the colonial elites came together and established informal alliances. Whereas

\footnotetext{
$99 \quad$ Ibid., 13.

100 Ibid.

101 Dachs and Rea, Catholic Church and Zimbabwe, 42.
} 
the missionaries established an alliance with the BSAC out of the belief that it would bring about the much-needed change for evangelization, the company wanted an alliance that would shield them from criticism by humanitarian groups back home. In the end, the resolve to depose African chiefs, and the facilitation of colonial elites toward that goal, turned the Jesuits and Protestants into "sisters" within the African missionary terrain.

\section{Bibliography}

Anderson, Holmberg. African Tribes and European Agencies: Colonialism and Humanitarianism in British South East Africa, 1870-1895. Stockholm: Scandinavian University Books, 1966.

Bangert, William V. A History of the Society of Jesus. St. Louis: Institute of Jesuit Sources, 1972.

Bhebe, Ngwabi. Christianity and Traditional Religion in Western Zimbabwe, 1859-1923. London: Longman, 1979.

Blake, Robert. A History of Rhodesia. London: Eyre Methuen, 1977.

Briggs, H.O. "New Development in Mashonaland and Matabeleland and the African Response to Christianity 1897-1918." http://journals.co.za/docserver/fulltext/ zambezia/1891-1945/1/303.pdf?expires $=1492096428 \&$ id $=i d \&$ accname=guest\&chec ksum=136A38F8ECoA8822742E19E105996CD6 (accessed April 13, 2017).

Chirenje, Jackson Mutero. Chief Kgama and His Times, c. 1835-1923: The Story of a Southern African Ruler. London: Rex Collings, 1978.

Chirenje, Jackson Mutero. A History of Northern Botswana 1850-1910. Rutherford: Dickinson Fairleigh University Press, 1977 .

Dachs, A. [Anthony] J., and W.F. [William Francis] Rea. The Catholic Church and Zimbabwe 1879-1979. Gwelo: Mambo Press, 1979.

Denoon, Donald, and Balam Nyeko. Southern Africa since 180o. London: Longman Group, 1984.

Gabatshwane, Sidwell Mhaladi. Introduction to the Bechuanaland Protectorate History and Administration. Botswana: Kanye, 1957.

Gale, W.D. [William Daniel]. Heritage of Rhodes. London: Oxford University Press, 1950. Gann, Lewis H. A History of Southern Rhodesia: Early Days to 1934. London: Chatto \& Windus, 1965 .

Hole, Hugh Marshall. Lobengula. London: Philip Allan \& Co., 1929.

Mockford, Julian. Seretse Khama and the Bamangwato. London: Staples Press, 1950.

Mtshali, Benedict V. Rhodesia: Background to Conflict. London: Leslie Frewin, 1968.

Ndlovu-Gatsheni, Sabelo J. "Beyond the Equator There Are No Sins: Coloniality of Being and Violence in Africa." Journal of Developing Societies 28, no. 4 (2012): 419-40. 
Ndlovu-Gatsheni, Sabelo J. "Rethinking Religious Encounters in Matabeleland Region of Zimbabwe, 1860-1893." African Journal of History and Culture 1, no. 2 (2009): 16-27.

Ndlovu-Gatsheni, Sabelo J. "Who Ruled by the Spear? Rethinking the Form of Governance in the Ndebele State." African Studies Quarterly 10, nos. 2-3 (2008): 71-94.

Noble, Frederic Perry. The Redemption of Africa: A Story of Civilization, 2 vols. New York: Young People's Missionary Movement.

Richartz, Francis S.J. “Chishawasha Today." Zambesi Mission Record 1, no. 14 (1901): 471-75.

Wakerley, Véronique, trans. Journeys beyond Gubuluwayo to the Gaza, Tonga and Lozi: Letters of The Jesuits' Zambesi Mission, 1880-1883. Edited by Ray S. Roberts. Harare: Weaver Press, 2009.

Zvobgo, Chengetai J.M. A History of Christian Missions in Zimbabwe. Gweru: Mambo Press, 1996. 